\title{
Combined use of cyclophosphamide and Chalone 19-peptide in experimental breast cancer
}

This article was published in the following Dove Press journal:

OncoTargets and Therapy

9 July 2013

Number of times this article has been viewed

\author{
Yuanxi Huangl,* \\ Yan $\mathrm{He}^{2, *}$ \\ Shengqian $\mathrm{Ye}^{2}$ \\ Xiaomei $\mathrm{Li}^{\prime}$ \\ Qingqi Zhong' \\ Zhuo Chen' \\ Xiaoming Jin ${ }^{2}$ \\ 'Third Affiliated Hospital, \\ ${ }^{2}$ Department of Pathology, Harbin \\ Medical University, Harbin, \\ Heilongjiang, People's Republic \\ of China \\ *These authors contributed equally \\ to this work
}

Correspondence: Xiaoming jin

Department of Pathology, Harbin Medical University, I57 Baojian Road, Nangang District, Harbin, Heilongjiang I5008I, People's Republic of China

Tel +86045I 86669472

Email jinxm55@I63.com
Background: Cyclophosphamide is a potent anticancer drug, but its clinical utility is limited because of its severe side effects, in particular liver damage. Chalone 19-peptide induces apoptosis of tumor cells and inhibits tumor growth. The present study investigated the antitumor effects of a combination of cyclophosphamide and Chalone 19-peptide in experimental breast cancer.

Methods: An animal model of breast cancer was developed, consisting of an MDA-MB-231 cell line implanted in the nude mouse. Eight doses of a combination of cyclophosphamide $50 \mathrm{mg} / \mathrm{kg}$ or $100 \mathrm{mg} / \mathrm{kg}$ and Chalone 19-peptide $6.6 \mathrm{mg} / \mathrm{kg}$ were administered, and the mice were euthanized 28 days after the final drug injection. Histopathologic analysis of tumor size, metastasis, and apoptosis of cancer cells was performed. Control mice were injected intraperitoneally with either cyclophosphamide alone or the same volume of solvent.

Results: Tumor sizes in the treatment groups were smaller than in the controls. No metastasis was found in the groups treated with cyclophosphamide and Chalone 19-peptide, but lung metastasis was found in controls. Liver damage in the groups treated with cyclophosphamide was more serious than in the other groups.

Conclusion: Addition of Chalone 19-peptide can improve the ability of cyclophosphamide to inhibit tumor growth and also reduces side effects.

Keywords: cyclophosphamide, Chalone 19-peptide, tumor suppression, apoptosis, hepatic injury

\section{Introduction}

Surgery is usually the first choice in the treatment of malignant solid tumors. However, chemotherapy becomes important for advanced malignancies where surgery is not feasible, in the event of disease recurrence, and when metastasis occurs after surgery. Choosing the best chemotherapeutic agents to kill tumor cells and inhibit tumor growth is important. At the same time, these drugs should cause minimal damage to normal cells, in particular hepatocytes.

Cyclophosphamide is widely used in the treatment of cancer, and its antitumoral activity is well established. ${ }^{1}$ However, while cyclophosphamide inhibits growth and reproduction of tumor cells, it also affects growth of normal cells. Therefore, researchers working in the field of cancer are continuing the search for drugs with both a strong antitumor effect and a good safety profile. ${ }^{2-5}$ Tumstatin, identified in the 1980s to be an autoantigen involved in Goodpasture syndrome, suppresses tumor cell growth either directly or indirectly and promotes apoptosis of tumor cells via the activity of two antineoplastic fragments, one of which is the 19-peptide, comprising 
amino acids $185-203$ of the collagen IVa3 chain. ${ }^{6}$ Chalone 19-peptide is a newly identified antitumor compound that inhibits tumor growth by inducing apoptosis of tumor cells with minimal damage to hepatic tissue. ${ }^{7,8}$ A combination of cyclophosphamide and Chalone 19-peptide could have a synergistic antitumor effect and fewer side effects, so is an attractive antitumor strategy.

\section{Materials and methods Materials and reagents}

Thirty-eight nude mice (aged 4-6 weeks, weight 18-20 g, 19 females and 19 males) were sourced from the Wei Tong Li Hua Laboratory Animal Center (Beijing, People's Republic of China). Animal handling and care followed the standard specific pathogen-free breeding protocol at the laboratory animal center of the Third Affiliated Hospital of Harbin Medical University. A MDA-MB-231 breast carcinoma cell line was sourced from the Shanghai Cell Biological Institute (Shanghai, People's Republic of China). Chalone 19-peptide was supplied by Shanghai GL Biochemistry (Shanghai, People's Republic of China). Cyclophosphamide was purchased from Beijing Bangding Biology (Beijing, People's Republic of China). Dulbecco's Modified Eagle's Medium and fetal calf serum were obtained from Sigma (St Louis, MO, USA). Mouse antihuman phosphatase and tensin homolog deleted on chromosome ten (PTEN) and proliferating cell nuclear antigen (PCNA) monoclonal antibodies and caspase 3 and FAK polyclonal antibodies were purchased from Santa Cruz Biotechnology (Santa Cruz, CA, USA). Goat antihuman pAkt monoclonal antibody was sourced from Beijing Zhongshan Goldbridge Biotechnology (Beijing, People's Republic of China). A terminal deoxynucleotidyl transferase biotin-dUTP nick end labeling (TUNEL) assay kit was supplied by Boster Bioengineering (Wuhan, People's Republic of China). A fluorescein isothiocyanate secondary antibody was obtained from Vector Laboratories (Burlingame, CA, USA).

\section{Animal model of breast carcinoma}

MDA-MB-231 cells were cultured in high-glucose Dulbecco's Modified Eagle's Medium containing 10\% fetal calf serum at $37^{\circ} \mathrm{C}$ and $5 \% \mathrm{CO}_{2}$. The cells were then collected during the exponential growth phase and stained with Trypan blue for a viable cell count, which should be more than $95 \%$.

Thirty-two nude mice were randomly allocated to receive cyclophosphamide, Chalone 19-peptide, or a combination of both treatments, with eight mice in each group. Six mice were used as controls. Each mouse underwent injection of $2 \times 10^{7}$
MDA-MB-231 cells per $1 \mathrm{~mL}$ into the second mammary fat pad, and all developed tumors by ten days following inoculation. Cyclophosphamide and Chalone 19-peptide were injected intraperitoneally on alternate days. The group allocated to combination therapy received Chalone 19-peptide $6.6 \mathrm{mg} / \mathrm{kg}$ and cyclophosphamide $50 \mathrm{mg} / \mathrm{kg}$ or $100 \mathrm{mg} / \mathrm{kg}$. The same volume of solvent was injected intraperitoneally in the controls. Each treatment group received a total of eight injections and were euthanized 28 days after the final drug injection.

\section{Tumor formation and effects of treatment}

Tumor size and clinical status were checked in each mouse during generation of the tumors. Tumor volume $=\left(a \times b^{2}\right) / 2$, where $\mathrm{a}$ is length and $\mathrm{b}$ is breadth. After treatment, the tumors were examined by light microscopy to evaluate tumor growth, metastasis, and hepatic injury. Immunohistochemistry and Western blotting were performed to observe apoptosis of tumor cells and the pathway of apoptosis. All the procedures used for immunohistochemistry and Western blotting were performed as described elsewhere. ${ }^{7}$ Antibodies for PTEN (1:100 dilution, sc-7974), FAK (1:200 dilution, sc-1289), pAkt (1:100 dilution, sc-135651), and caspase 3 (1:200 dilution, sc-6840) were used. The tumor cell proliferation rate was determined by calculating the ratio of cells positive for PCNA (1:100 dilution) to all tumor cells per high power field $(40 \times)$ in three tumor samples, and 3-5 high-power fields per sample for each group. For the TUNEL assay, the cells were stained using an in situ cell death detection kit (Roche, Mannheim, Germany). All procedures were performed according to the instructions of the manufacturer.

\section{Statistical analysis}

Analysis of variance and Dunnett's $t$-test were used to identify differences between data in the three animal groups using the Statistical Package for the Social Sciences version 17.0 software (SPSS Inc, Chicago, IL, USA). $P<0.05$ was considered to indicate a statistically significant difference.

\section{Results}

\section{Evaluation of animal tumor model}

All the nude mice lost weight before being euthanized. During formation of their tumors, all reduced their physical activity and became lethargic. They also ate less, drank water less often, and developed dry and crinkly skin. As shown in Figure 1, the in vivo tumor sizes in the active treatment groups were smaller than in controls $(P<0.05)$, 

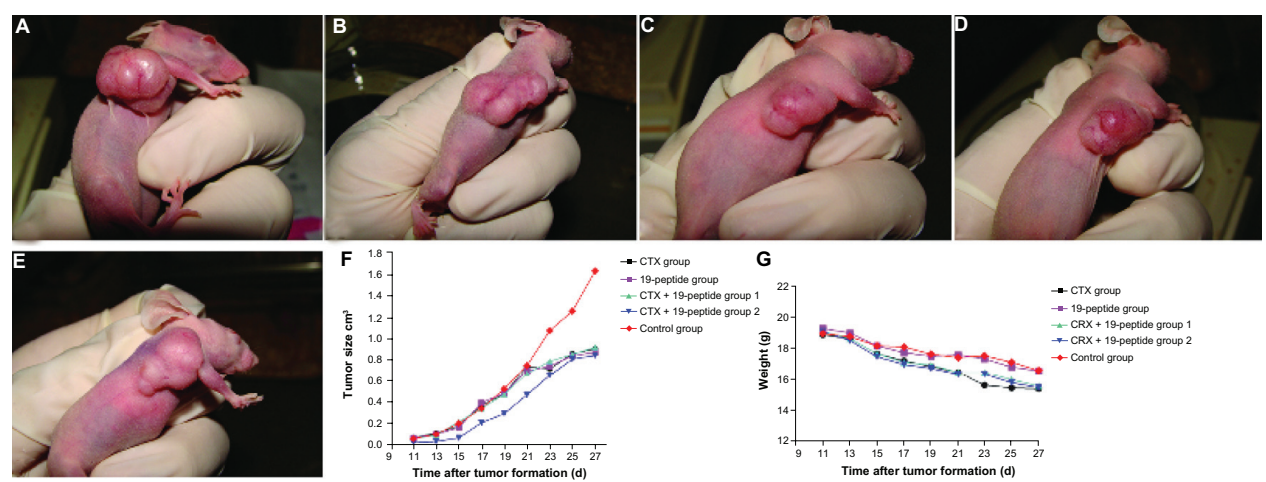

G
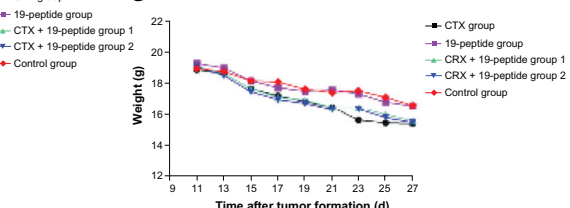

Figure I Over a period of I0 days, a MDA-MB-23I model of breast cancer was established in mice, after which eight intraperitoneal injections of Chalone I9-peptide $6.6 \mathrm{mg} / \mathrm{kg}$ and cyclophosphamide $50 \mathrm{mg} / \mathrm{kg}$ or $100 \mathrm{mg} / \mathrm{kg}$ were given. The mice were sacrificed 28 days after the final injection. Photographs showing mice from the (A) Cyclophosphamide $100 \mathrm{mg} / \mathrm{kg}$ group, (B) Chalone 19-peptide $6.6 \mathrm{mg} / \mathrm{kg}$ group, (C) cyclophosphamide $100 \mathrm{mg} / \mathrm{kg}$ and Chalone $19-$ peptide $6.6 \mathrm{mg} / \mathrm{kg}$ group, (D) cyclophosphamide $50 \mathrm{mg} / \mathrm{kg}$ and Chalone 19-peptide $6.6 \mathrm{mg} / \mathrm{kg}$ group, and (E) control group. (F) Relationship between tumor formation time and volume, showing that mean tumor size was smaller in the active treatment groups than in controls $(P<0.05)$. (G) Relationship between tumor formation time and weight in tumor-bearing nude mice.

Abbreviation: CTX, cyclophosphamide.

but there were no differences in tumor size between the active treatment groups $(P>0.05)$.

Histologic examination by light microscopy showed that the tumors were in various degrees of necrosis. Tumor invasion into the peripheral tissues was observed, with an incomplete capsule or no capsule at all. Some tumors even invaded the peripheral skeletal muscles and broke through the skin. Most of the tumors were actively growing around blood vessels. No metastases were found in the groups treated with cyclophosphamide at either dose or the group treated with Chalone 19-peptide, but lung metastasis was found in the controls.

Severe liver damage with widespread necrosis and punctate hemorrhage was seen in the cyclophosphamide group. In the group treated with Chalone 19-peptide, there was slight liver tissue damage with hydropic degeneration, diffuse hyperplasia, and hypertrophy of sinusoidal epithelial cells.

Hydropic degeneration and sporadic fatty degeneration of liver cells was seen in the group receiving combination treatment including the higher dose of cyclophosphamide, whereas hepatic tissue in the group receiving combination treatment including the lower dose of cyclophosphamide showed punctate phagocytic infiltration. Only slight phagocytic infiltration was noted in the controls (Figure 2).

\section{Apoptosis in tumor cells}

Immunohistochemistry showed that caspase 3 expression in tumor cell nuclei was greater in the group treated with Chalone 19-peptide alone and the combined treatment groups compared with that in the cyclophosphamide only group and controls (Figure 3). Also, there were greater numbers of TUNEL-labeled tumor cells in the Chalone 19-peptide group and combined treatment groups compared with those in the cyclophosphamide only group and controls (Figure 3).

PTEN expression in cytoplasm was higher in all active treatment groups than in controls. However, there was higher expression of pAKt and PCNA in the cell nuclei of controls than in the active treatment groups (Figure 4). Protein expression tested by Western blotting showed that PTEN and caspase 3 expression was higher in the active treatment groups compared with controls and that $\mathrm{pAKt}$ expression was lower in the active treatment groups than in controls (Figure 5).

\section{Discussion}

Cyclophosphamide is an alkylating agent that has been in clinical use for more than 50 years, and exerts its antitumoral effect by inducing cross-linkage of DNA in cancer cells. In addition to inhibiting growth and reproduction of cancer cells, cyclophosphamide also affects the growth of normal cells and destroys immunocytes. The percentage of $\mathrm{T}$ cells and expression of CD25+ and CD4+ on T cells has been shown to be decreased markedly by cyclophosphamide. ${ }^{9,10}$ Hepatosis and hepatocyte damage is also found during treatment with this agent, so cyclophosphamide destroys both tumor cells and immunocytes. Researchers have shown that low doses of cyclophosphamide destroy regulatory $\mathrm{T}$ cells but have no effect on tumor cells and other immunocytes. ${ }^{11}$

Tumstatin has been identified as the autoantigen involved in Goodpasture syndrome and found to have two functional positions. ${ }^{6}$ One of these comprises 19 amino acids located at 185-203 near the $\mathrm{C}$ terminus, and is known as Chalone 19-peptide, which can suppress proliferation and promote apoptosis of tumor cells. ${ }^{12,13}$ Increasing research attention is 


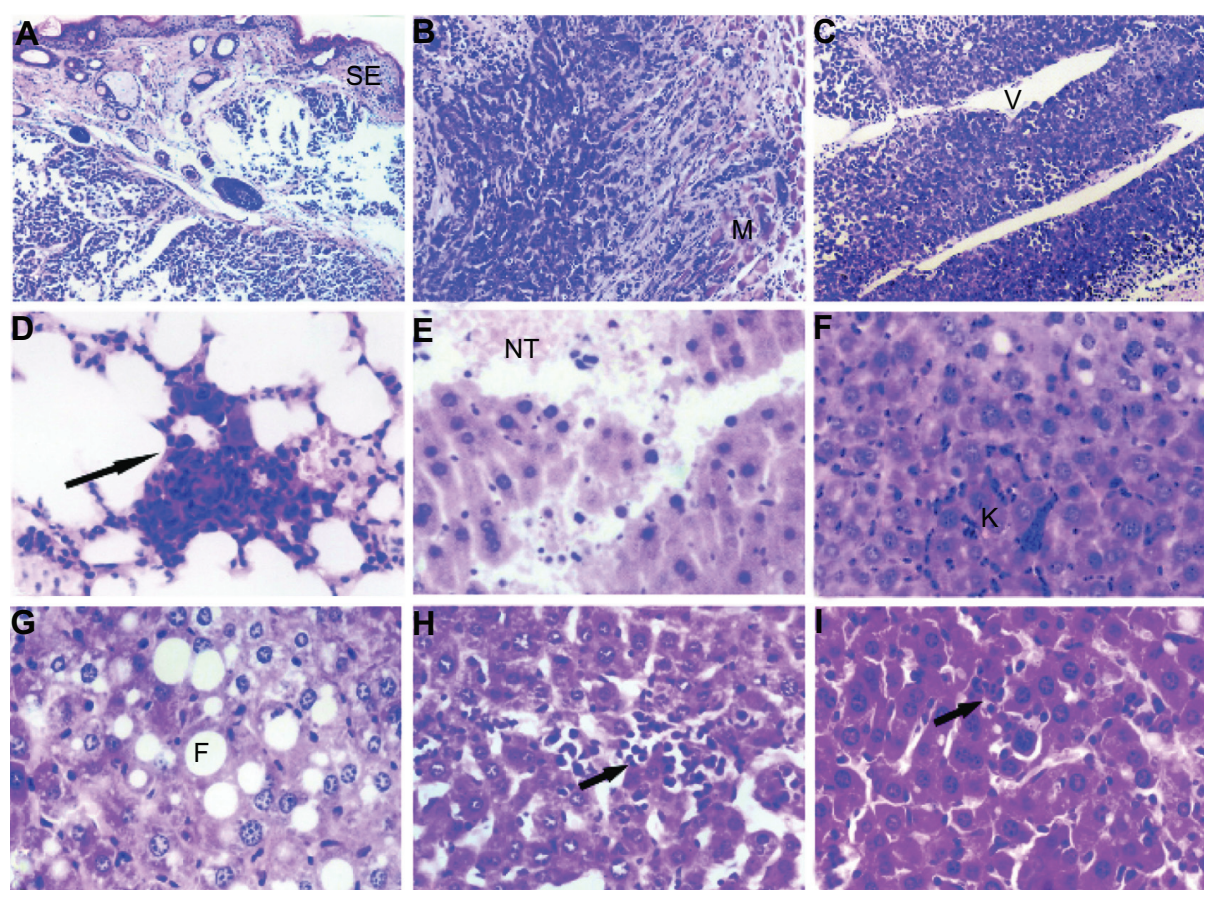

Figure 2 (A) Animal model control group with tumor cell wear through skin squamous epithelium, $\mathrm{HE} \times 120$. (B) Animal model control group with tumor cell invasion to skeletal muscles, $\mathrm{HE} \times 120$. (C) Animal model control group with tumor cells actively around blood vessels, $\mathrm{HE} \times 120$. (D) Animal model control group showing pulmonary metastasis, $\mathrm{HE} \times 460$. (E) Cyclophosphamide group with hemorrhage and necrotic tissue in liver, $\mathrm{HE} \times 460$. (F) Chalone 19-peptide group showing hydropic degeneration in hepatic cells, $\mathrm{HE} \times 460$. (G) Cyclophosphamide $100 \mathrm{mg} / \mathrm{kg}$ and Chalone 19-peptide combined treatment group showing fatty degeneration of tumor cells, HE $\times 460$. (H) Cyclophosphamide $50 \mathrm{mg} / \mathrm{kg}$ and Chalone 19-peptide combination treatment group showing punctuate phagocytic infiltration, HE $\times 460$. (I) Control group with slight phagocytic infiltration, $\mathrm{HE} \times 460$.

Abbreviations: CTX, cyclophosphamide; HE, hematoxylin and eosin staining; SE, squamous epithelium; M, skeletal muscle; NT, necrotic tissue; K, Kupffer cell; V, bloodvessel; F, fatty degeneration; $V$, blood vessels.

now focusing on Chalone 19-peptide because of its lower molecular weight, potent antitumoral effects, favorable safety profile, and flexible dosing options. Our research has demonstrated that Chalone 19-peptide exerts its antitumor effects by inducing apoptosis of tumor cells..$^{7,8,14}$ Combined treatment using cyclophosphamide and Chalone 19-peptide may have an increased antitumoral effect while reducing damage to normal cells and immunocytes. The results of our present study indicate a high rate of apoptosis in animals receiving cyclophosphamide and Chalone 19-peptide.

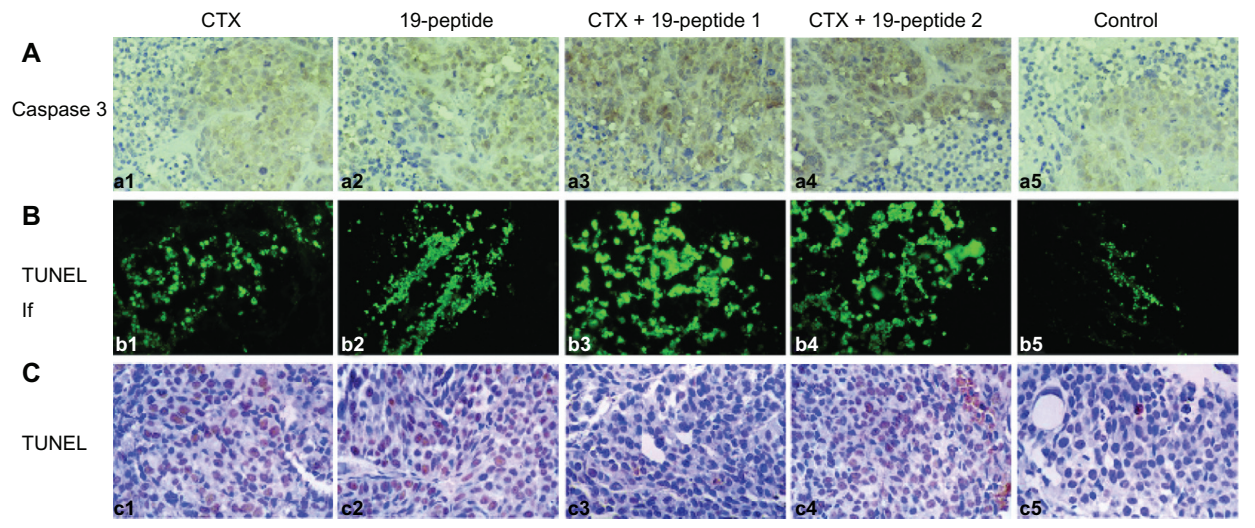

Figure 3 TUNEL analysis and immunohistochemistry testing of caspase 3 showing apoptosis in all four intervention groups relative to controls. (A) Immunohistochemistry testing of caspase 3. (al) Cyclophosphamide group, (a2) Chalone 19-peptide group, (a3) Cyclophosphamide $100 \mathrm{mg} / \mathrm{kg}$ and Chalone 19 -peptide combined treatment group, (a4) Cyclophosphamide $50 \mathrm{mg} / \mathrm{kg}$ and Chalone 19-peptide combined treatment group, and (a5) control group ( $\times 460)$. (B) Immunofluorescence testing of TUNEL. (bI) Cyclophosphamide group, (b2) Chalone 19-peptide group, (b3) Cyclophosphamide $100 \mathrm{mg} / \mathrm{kg}$ and Chalone 19-peptide combined treatment group, (b4) Cyclophosphamide $50 \mathrm{mg} / \mathrm{kg}$ and Chalone 19-peptide combined treatment group, and (b5) control group $(\times 460)$. (C) Immunohistochemistry testing of TUNEL. (cl) Cyclophosphamide group, (c2) Chalone 19-peptide group, (c3) Cyclophosphamide $100 \mathrm{mg} / \mathrm{kg}$ and Chalone 19-peptide combined treatment group, (c4) Cyclophosphamide $50 \mathrm{mg} / \mathrm{kg}$ and Chalone 19-peptide combined treatment group, and (c5) control group $(\times 460)$.

Abbreviations: TUNEL, terminal deoxynucleotidyl transferase biotin-dUTP nick end labeling; CTX, cyclophosphamide; If, immunofluorescence. 


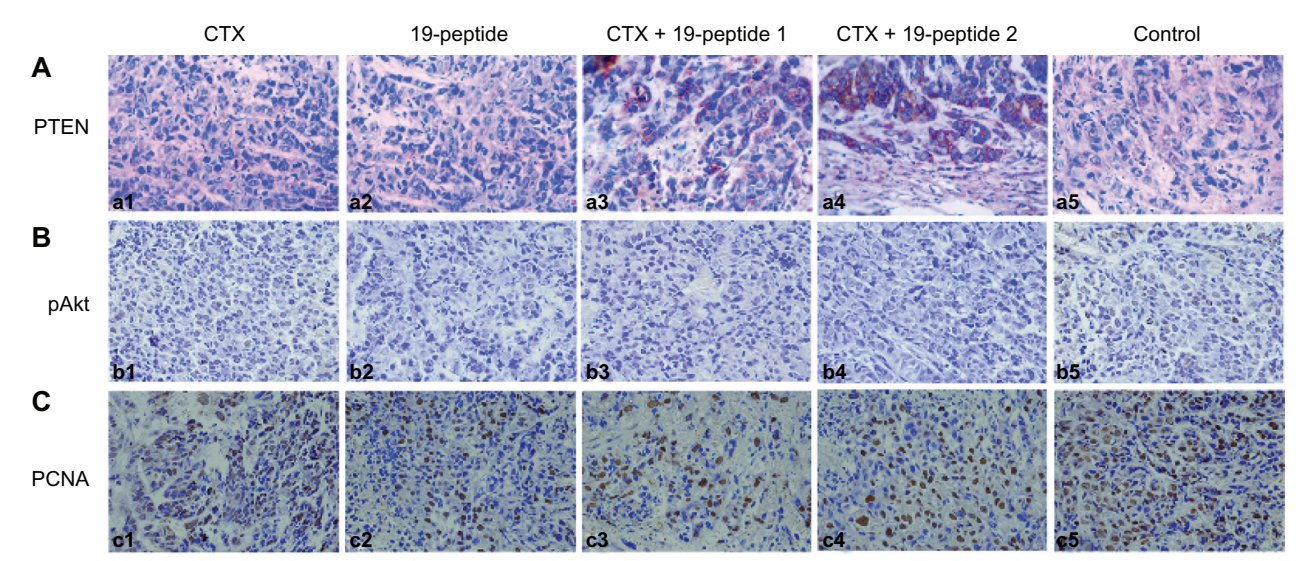

Figure $4 \mathrm{Immunohistochemistry} \mathrm{revealing} \mathrm{different} \mathrm{proteins} \mathrm{in} \mathrm{intervention} \mathrm{groups} \mathrm{relative} \mathrm{to} \mathrm{controls.} \mathrm{Micrographs} \mathrm{of} \mathrm{cells} \mathrm{after} \mathrm{immunohistochemistry} \mathrm{showing} \mathrm{that}$ PTEN, pAKt, and proliferating cells were produced by the different groups. After treatment with cyclophosphamide and/or Chalone 19-peptide, PTEN was increased. pAkt and PCNA were decreased and necrosis was observed (×460). (A) Immunohistochemistry testing of PTEN. (a I) Cyclophosphamide group, (a2) Chalone 19-peptide group, (a3) Cyclophosphamide $100 \mathrm{mg} / \mathrm{kg}$ and Chalone 19-peptide combined treatment, (a4) Cyclophosphamide $50 \mathrm{mg} / \mathrm{kg}$ and Chalone 19 -peptide combined treatment group, and (a5) control group. (B) Immunohistochemistry testing of pAkt. (bI) Cyclophosphamide group, (b2) Chalone 19-peptide group, (b3) Cyclophosphamide $100 \mathrm{mg} / \mathrm{kg}$ and Chalone 19-peptide combined treatment group, (b4) Cyclophosphamide $50 \mathrm{mg} / \mathrm{kg}$ and Chalone 19-peptide combined treatment group, and (b5) control group. (C) Immunohistochemistry testing of PCNA. (cl) Cyclophosphamide group, (c2) Chalone 19-peptide group, (c3) Cyclophosphamide I00 mg/kg and Chalone 19-peptide combined treatment group, (c4) Cyclophosphamide $50 \mathrm{mg} / \mathrm{kg}$ and Chalone 19-peptide combined treatment group, and (c5) control group.

Abbreviations: CTX, cyclophosphamide; PTEN, phosphatase and tensin homolog deleted on chromosome ten; PCNA, proliferating cell nuclear antigen.

Apoptosis is a natural form of genetically determined cell death which occurs as a cascade of reactions regulated by caspases. Among these, caspase 3, located downstream of this cascade, destroys its target cells by degrading their substrates, and this can occur via an extracellular pathway and an intracellular pathway. ${ }^{15-17}$ Most of the signals for apoptosis are mediated via the PI3K/Akt pathway. PTEN inhibits PI3K, thereby suppressing tumor growth, and signaling between PTEN and PI3K plays an important role in controlling cell survival. ${ }^{18}$ When PTEN is inactivated by a genetic mutation, PI3K and Akt become activated, leading to development of tumors. The PTEN/Akt signaling pathway is important for reproduction and growth of cells, apoptosis, control of the cell cycle, and formation of blood vessels. ${ }^{19}$ Research has demonstrated inactivation of PTEN in many tumor models. PTEN can negatively regulate the PI3K/Akt signal pathway mediating cell survival by promoting reproduction of cells and inhibiting apoptosis. ${ }^{20}$

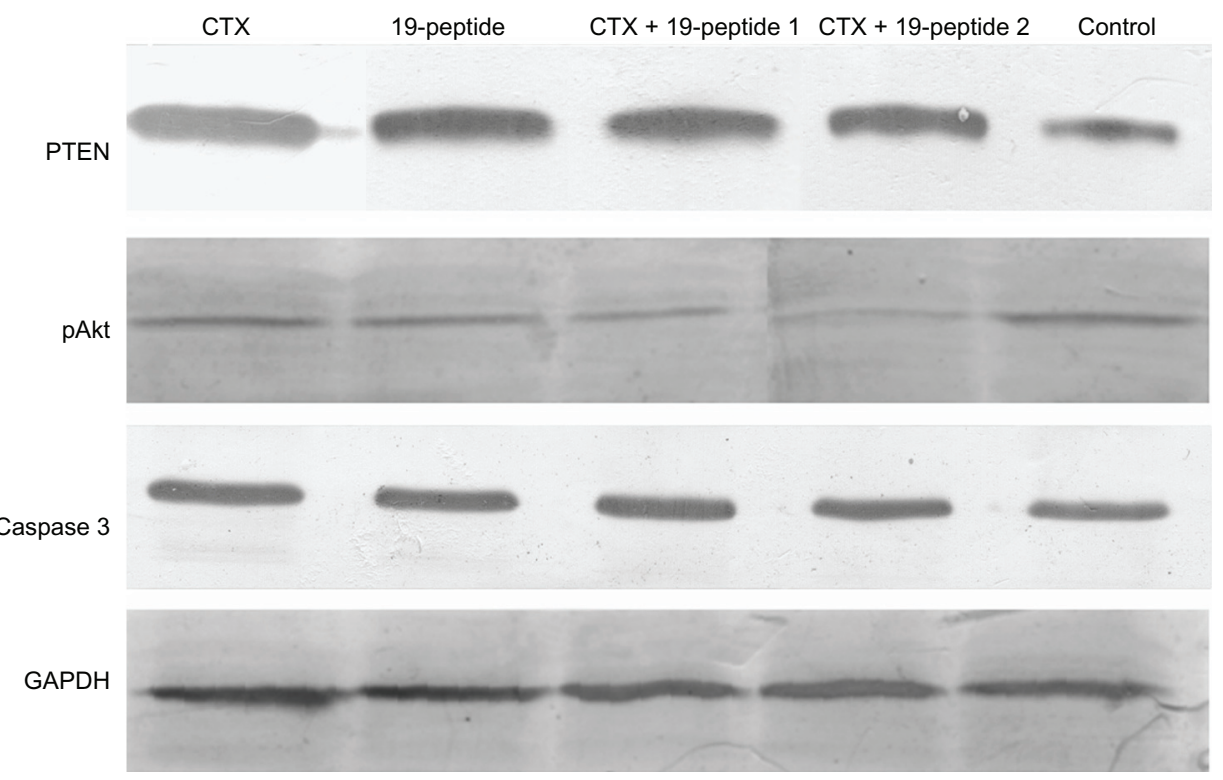

Figure 5 Western blotting revealed different protein expression in all four intervention groups relative to that in the control group. PTEN and caspase 3 were increased after treatment with cyclophosphamide and/or Chalone 19-peptide. pAkt expression was decreased in the treatment group.

Abbreviations: CTX, cyclophosphamide; PTEN, phosphatase and tensin homolog deleted on chromosome ten; pAkt, phosphorylated Akt; GAPDH, glyceraldehyde-3phosphate dehydrogenase. 
Both PI3 $\mathrm{K}$ and PTEN have phosphorylating and dephosphorylating roles, and maintain a balance between PIP2 and PIP3. When PTEN is inactivated, PIP3 cannot be dephosphorylated to PIP2, and an increase in PIP3 activates the Akt pathway. ${ }^{21}$ Researchers have also reported greater microvessel density and vascular endothelial growth factor (VEGF) expression in PTEN-negative gastric carcinoma. ${ }^{22}$ Increased expression of VEGF can increase the density of microvessels, and decreased expression of PTEN may upregulate VEGF, thereby causing vessel formation. In our study, expression of the proteins for PTEN and caspase 3 was higher in the active treatment groups compared with the controls, indicating decreased angiogenesis in the treatment groups, none of which showed metastatic disease.

The standard method used to evaluate the clinical value of a potential anticancer drug includes assessment of tumor volume, invasive growth into surrounding tissues, remote metastasis, and extent of liver damage. Invasive growth and severe hepatic damage were found in the group treated with cyclophosphamide alone, with no metastasis found in the groups treated with cyclophosphamide and Chalone 19-peptide, indicating that combined use of these two agents improves the antitumor effect of cyclophosphamide.

\section{Conclusion}

Antitumor drugs often damage the liver and lead to hepatosis, which eventually forces patients to abandon chemotherapy. When selecting chemotherapy, it can be useful to combine two or more drugs to allow a decrease in dosage, reduce side effects, and improve antitumor efficacy. Combined use of cyclophosphamide and Chalone 19-peptide can augment the ability of cyclophosphamide to inhibit tumor growth and may reduce side effects.

\section{Acknowledgments}

This work was supported by Program for New Century Excellent Talents In Heilongjiang Provincial University (NCET, 2013), grants from the National Natural Science Foundation of China (No. 81101735), grants from Heilongjiang Provincial Natural Science Foundation (D200639) and Harbin Scientific and Technological Talents Research Program (2008RFXQS037).

\section{Disclosure}

The authors report no other conflicts of interest in this work.

\section{References}

1. Pelaez B, Campillo JA, Lopez-Asenjo JA, Subiza JL. Cyclophosphamide induces the development of early myeloid cells suppressing tumor cell growth by a nitric oxide-dependent mechanism. J Immunol. 2001;166(11):6608-6615.

2. Man S, Bocci G, Francia G, et al. Antitumor effects in mice of low-dose (metronomic) cyclophosphamide administered continuously through the drinking water. Cancer Res. 2002;62(10):2731-2735.

3. Nakamura Y, Kunitoh H, Kubota K, et al. Retrospective analysis of safety and efficacy of low-dose docetaxel $60 \mathrm{mg} / \mathrm{m}^{2}$ in advanced nonsmall cell lung cancer patients previously treated with platinum-based chemotherapy. Am J Clin Oncol. 2003;26(5):459-464.

4. Ghiringhelli F, Larmonier N, Schmitt E, et al. CD4+CD25+ regulatory T cells suppress tumor immunity but are sensitive to cyclophosphamide which allows immunotherapy of established tumors to be curative. Eur J Immunol. 2004;34(2):336-344

5. Salem ML, Al-Khami AA, El-Naggar SA, Diaz-Montero CM, Chen Y, Cole DJ. Cyclophosphamide induces dynamic alterations in the host microenvironments resulting in a Flt3 ligand-dependent expansion of dendritic cells. J Immunol. 2010;184(4):1737-1747.

6. Maeshima Y, Colorado PC, Torre A, et al. Distinct antitumor properties of a type IV collagen domain derived from basement membrane. $J$ Biol Chem. 2000;275(28):21340-21348.

7. He Y, Jiang Y, Li YJ, et al. 19-peptide, a fragment of tumstatin, inhibits the growth of poorly differentiated gastric carcinoma cells in vitro and in vivo. J Gastroenterol Hepatol. 2010;25(5):935-941.

8. Huan Y, He Y, Liu M, et al. A comparative study of tumor-suppression effects of enterotoxin $\mathrm{B}$ and Chalone 19-peptide on experimental gastric carcinoma. Hepatogastroenterology. 2009;56(89):270-275.

9. Ikezawa Y, Nakazawa M, Tamura C, Takahashi K, Minami M, Ikezawa Z. Cyclophosphamide decreases the number, percentage and the function of $\mathrm{CD} 25+\mathrm{CD} 4+$ regulatory $\mathrm{T}$ cells, which suppress induction of contact hypersensitivity. J Dermatol Sci. 2005;39(2):105-112.

10. Ghiringhelli F, Menard C, Puig PE, et al. Metronomic cyclophosphamide regimen selectively depletes $\mathrm{CD} 4+\mathrm{CD} 25+$ regulatory $\mathrm{T}$ cells and restores $\mathrm{T}$ and $\mathrm{NK}$ effector functions in end stage cancer patients. Cancer Immunol Immunother. 2007;56(5):641-648.

11. Cao Y, Zhao J, Yang Z, et al. CD4+FOXP3+ regulatory T cell depletion by low-dose cyclophosphamide prevents recurrence in patients with large condylomata acuminata after laser therapy. Clin Immunol. 2010;136(1):21-29.

12. Maeshima Y, Yerramalla UL, Dhanabal M, et al. Extracellular matrix-derived peptide binds to alpha(v)beta(3) integrin and inhibits angiogenesis. J Biol Chem. 2001;276(34):31959-31968.

13. Hamano Y, Kalluri R. Tumstatin, the NC1 domain of alpha3 chain of type IV collagen, is an endogenous inhibitor of pathological angiogenesis and suppresses tumor growth. Biochem Biophys Res Commun. 2005;333(2):292-298.

14. Li YJ, Sun LC, He Y, et al. The anti-tumor properties of two tumstatin peptide fragments in human gastric carcinoma. Acta Pharmacol Sin. 2009;30(9):1307-1315.

15. Porter AG, Janicke RU. Emerging roles of caspase-3 in apoptosis. Cell Death Differ. 1999;6(2):99-104.

16. Grutter MG. Caspases: key players in programmed cell death. Curr Opin Struct Biol. 2000;10(6):649-655.

17. Hishikawa K, Nakaki T, Fujii T. Connective tissue growth factor induces apoptosis via caspase 3 in cultured human aortic smooth muscle cells. Eur J Pharmacol. 2000;392(1-2):19-22.

18. Fresno-Vara JA, Casado E, de Castro J, Cejas P, Belda-Iniesta C, Gonzalez-Baron M. PI3 K/Akt signalling pathway and cancer. Cancer Treat Rev. 2004;30(2):193-204

19. Salmena L, Carracedo A, Pandolfi PP. Tenets of PTEN tumor suppression. Cell. 2008;133(3):403-414. 
20. Stambolic V, Suzuki A, de la Pompa JL, et al. Negative regulation of PKB/Akt-dependent cell survival by the tumor suppressor PTEN. Cell. 1998;95(1):29-39.

21. Maehama T, Dixon JE. The tumor suppressor, PTEN/MMAC1, dephosphorylates the lipid second messenger, phosphatidylinositol 3,4,5-trisphosphate. J Biol Chem. 1998;273(22):13375-13378.
22. Zheng HC, Li YL, Sun JM, et al. Growth, invasion, metastasis, differentiation, angiogenesis and apoptosis of gastric cancer regulated by expression of PTEN encoding products. World $J$ Gastroenterol. 2003;9(8):1662-1666.

\section{Publish your work in this journal}

OncoTargets and Therapy is an international, peer-reviewed, open access journal focusing on the pathological basis of all cancers, potential targets for therapy and treatment protocols employed to improve the management of cancer patients. The journal also focuses on the impact of management programs and new therapeutic agents and protocols on

\section{Dovepress}

patient perspectives such as quality of life, adherence and satisfaction The manuscript management system is completely online and includes a very quick and fair peer-review system, which is all easy to use. Visit http://www.dovepress.com/testimonials.php to read real quotes from published authors.

\footnotetext{
Submit your manuscript here: http://www.dovepress.com/oncotargets-and-therapy-journal
} 